\title{
Efficacy of germination and probiotic fermentation on underutilized cereal and millet grains
}

\author{
Savita Budhwar ${ }^{1,2^{*}}$ (D) Kashika Sethi ${ }^{1,2}$ and Manali Chakraborty ${ }^{1,2}$
}

\begin{abstract}
Cereals and millets have been known as poor man's crops for a long time, and have good potential in the mercenary system of food and in research and development but these coarse grains have been leftover and underutilised since a long time. In addition to nutritional properties, various elements of cereal grains contain phenolic compounds as well as various anti-nutritional factors. To improve the nutritional quality and availability of these grains, they are processed in several ways. This review discusses the effect of pre-processing techniques such as germination with a combination of probiotic fermentation on various components of underutilised coarse cereals and millets and advantages it brings into the final product. Germinated food mixture usually contains a significantly higher amount of thiamine, lysine and niacin contents. The combination of cereals with other methods results in better nutrient profile and an enhanced amino acid pattern. Fermentation is said to be the most crucial and popular process which considerably lowers the antinutrients present in coarse cereals such as trypsin inhibitor, phytic acid and tannins and hence, enhance the overall nutritive value of coarse cereals and other food grains. Also, germinated cereal-based food products have higher cell count and better growth of beneficial bacteria, thus, germination of cereals facilitates the probiotic fermentation of cereals.
\end{abstract}

Keywords: Cereals, Germination, Probiotics, Antinutrients, Phenolic compounds

\section{Introduction}

Coarse cereal grains refer to those grains which are primarily used for animal feed or brewing purposes (Kaur et al. 2014). These coarse cereals are utilised in several parts of the world. They are generally popular and well-known for their ability to be utilised as food, feed and fodder. These coarse cereals are usually grown in the rain-fed farming system along with slight external inputs (Kaur et al. 2014). These are generally called as summer season grains. They are generally grown in those Asian and African regions which are semi-arid. The levels of grain yield are generally low $(<1 \mathrm{t} / \mathrm{ha})$ for these coarse cereals. Coarse cereals consist of wheat

\footnotetext{
* Correspondence: savitadahiya@cuh.ac.in

'Department of Nutrition Biology, School of Interdisciplinary and Applied Life Sciences, Central University of Haryana, Mahendragarh, Haryana 123031, India ${ }^{2}$ Department of Nutrition Biology, School of Interdisciplinary and Applied Life Sciences, Central University of Haryana, Mahendragarh, Haryana 123031, India
}

(Gehoon; Triticum aestivum, oats (Jai; Avena sativa), maize (Zea mays), barley (Jow; Hordeum vulgare), rye (Secale cereale), sorghum (Jowar; Sorghum vulgare), triticale (Triticosecale) and trivial millets for instance Finger millet (Ragi; Eleusine coracana), Barnyard millet (Sanwa; Echinochloa utilis), pearl millet (Bajra; Pennisetum glaucum), Foxtail millet (Kauni; Setaria), Kodo millet (Arikalu; Paspalum setaceum), Proso millet (Cheena; Panicum miliaceum) and Little millet (Kutki; Panicum sumatrense). All of these coarse grains and millets are abundant in various phytochemicals and insoluble dietary fibre with antioxidant properties, a variety of minerals (mainly micronutrients such as zinc, magnesium and iron), dietary energy and several vitamins (Agil and Hosseinian 2012). One of the richest sources of calcium is Finger millet with a value of the $300-350 \mathrm{mg} / 100 \mathrm{~g}$ grain (Table 1). Some varieties of coarse cereals and

(c) The Author(s). 2020 Open Access This article is licensed under a Creative Commons Attribution 4.0 International License, which permits use, sharing, adaptation, distribution and reproduction in any medium or format, as long as you give appropriate credit to the original author(s) and the source, provide a link to the Creative Commons licence, and indicate if changes were made. The images or other third party material in this article are included in the article's Creative Commons licence, unless indicated otherwise in a credit line to the material. If material is not included in the article's Creative Commons licence and your intended use is not permitted by statutory regulation or exceeds the permitted use, you will need to obtain permission directly from the copyright holder. To view a copy of this licence, visit http://creativecommons.org/licenses/by/4.0/. 


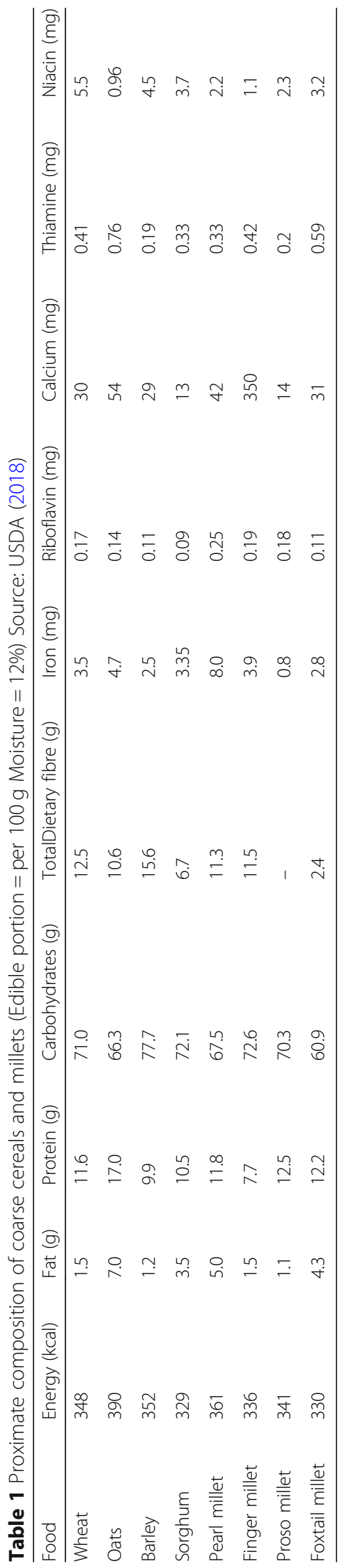


millets are rich in nutrients like phosphorus and iron (Kaur et al. 2014). In perspective of these nutritional properties that coarse cereals have, they are also designated as Nutri-cereals in the market. Cereal based foods are usually grown and build up in about $74 \%$ of the part of the world and contribute in the half of the global food produced (Charalampopoulos et al. 2002). Coarse cereals have been known as poor man's crops for a long time, and have good potential in the mercenary system of food and in research and development but these coarse grains have been leftover and underutilised since a long time. The nutritive and wellness facet of these coarse grains have an unsubstantiated agricultural understanding and a great scope and potential in scientific research (Sindhu and Khetarpaul 2001). Several types of food products can be prepared from these underutilised coarse cereals (Sindhu and Khetarpaul 2001). These coarse cereals have become successful in attracting a broad spectrum of consumers which includes people from both poor and rich community, and people who belong to both rural and urban setting in both developed and underdeveloped economies and resources (Das et al. 2012). The huge success of these cereal grains in the market is due to the constant degradation in the environment quality which further resulted in bad consequences on food and nutritional security and an understandable requirement for increasing the food production for continually increasing population (Das et al. 2012). The potential of these coarse grains for being utilised as formulated or functional foods has been researched. Coarse grains are not only limited to food uses, but also can be used as distilleries, bioethanol, feed, biopolymers, syrups and substrate for biofuels (Kaur et al. 2014). According to various previous studies, consumption of cereal grains and their products leads to the reduction of incidence of NCDs such as stroke, cardiovascular disease (CVDs), diabetes and various types of cancer related to oxidative stress (Kumari et al. 2019). Many pre-processing techniques are applied in cereal grains and two most important techniques are germination and probiotic fermentation. Germination is a well-known and traditional method to improve the nutrient profile of grains. In addition, germination has always been used for softening the structure of kernel and decreasing anti-nutritional factors (Gunenc et al. 2017). The main aim of germination is to induce the formation of hydrolytic enzymes that are not in active state in raw seeds. During germination, the biosynthetic capacity of cereal grains is utilized and various hydrolytic enzymes are developed. All these reactions in germinated grains result in structural modification and the formation of new compounds, which have bioactivity and can enhance the nutritional profile and the overall stability of cereal grains.

The other technique which is mostly used to improve the nutritional value of coarse grains is probiotic fermentation (Boudjou et al. 2014). Probiotics can be referred to as 'live microbial feed supplements' which subsequently act on the host subject in a beneficial way by enhancing its microbial balance (Fuller 1992). Probiotic strains have been with the humankind from the moment people started gobbling fermented foods and beverages (Kumar et al. 2015). However, their valuable health benefits were only found out after Metchnikoff (Father of probiotics) in 1907 reported that the gut microflora had detrimental effects on health and referred it autointoxication. Most widely used probiotics are various species belonging to the genera of Lactobacillus, Lactococcus, Streptococcus, Bifidobacterium and some species of Escherichia coli and Enterococcus. Saccharomyces boulardii is the only yeast which is non-pathogenic and is considered to be a probiotic. Treatment with probiotics includes modulating immune system at the local as well as at the systemic levels and beneficial effects of this include either diminished time-span of infections or lesser vulnerability to microorganisms (Antoine 2010). The basic mechanism of action of probiotics involves ingestion of probiotics. Probiotics, when ingested, have to surpass the acidic conditions of the gastrointestinal tract (GIT). Those cells that survive this harsh environment of the gut transit then colonize themselves and cling to the intestinal mucosa interacting with the host system. The first mechanism of probiotic action is inhibition of pathogen activity by releasing various metabolites and competing for sites of adhesion to the host epithelium.

The aim of this review is to discuss the functional and productive outcomes when coarse cereals are subjected to germination and fermentation, and to study the effect of germination and probiotic fermentation on various components of nutrient-rich coarse cereals and millets. Additionally, some of the cereal based fermented and germinated food and their advantages are also discussed.

\section{Bioactive compounds}

Bioactive compounds present in cereals and millets

Various elements of cereal grains and millets have biological activity. These bioactive compounds are also known as phytochemicals. Phenolic compounds are one of the highest varied group of phytochemicals. These phenolic compounds are found in all organs of plants and hence considered important in human diet. A distinctive range of free phenolic compounds as well as their glycosides and esters along with their insolublebound corresponding parts that are linked with polysaccharides exist in cell walls, are present in cereal and millet grains (Shahidi and Chandrasekara 2013). Those phenolics which are extracted into mixtures which are aqueous or aqueous-organic based are known as soluble phenolics (Shahidi and Chandrasekara 2013). Soluble phenolics consists of those phenolic compounds which 
exists in free, non-coupled form along with those phenolic compounds joined to soluble carbohydrates through ester and ether bonds (Shahidi and Chandrasekara 2013). Phenolic compounds which are mostly form ester bonds with polysaccharides providing cross-linkage between cell polymers are known as insoluble-bound phenolic compounds. The total phenolic content (TPC) of insoluble-bound, esterified, free and etherified sections of millet grains were ranged as 3.2-81.6, 0.25-2.02, $0.55-16.2$ and $0.32-3.94 \mu \mathrm{mol}$ ferulic acid equivalents (FAE)/g fat free meal respectively (Shahidi and Chandrasekara 2013).

Phenolic compounds or polyphenols present in cereals include flavonoids, phenolic acids, alkyl resorcinol and coumarins. In plant foods, phenols provide colour, oxidative stability, flavour, taste and texture (Naczk and Shahidi 2004). These compounds are principally located in bran and have nutraceutical properties. The two categories of phenolic acids are: hydroxycinnamic acid and hydroxybenzoic acid (Fig. 1). Hydroxycinnamic acid includes ferulic acid, caffeic acid, sinapic acid and $p$-coumaric acid whereas, on the other side, hydroxyl benzoic acids involve vanillic acid, protocatechuic acid, $p$-hydroxybenzoic acid and syringic acid. In millet grains, hydroxycinnamic acids and their derivatives (HCAS) are mostly located in the insoluble-bound phenolic fraction (Shahidi and Chandrasekara 2013). Dimers and trimers of ferulates which have relatively higher antioxidant potential have been accounted for in millet grains in addition to various monomeric compounds. In finger millet, it has been reported that the phenolic compounds are mostly in the free form (71\%). Major free phenolic acid among vanillic, ferulic, gallic and caffeic acid is protocatechuic acid ( $45 \mathrm{mg} / 100 \mathrm{~g}$ ) (Subba Rao and Muralikrishna 2002; Shahidi and Chandrasekara 2013). Flavonoids include flavones, flavanones, anthocyanins, flavonoids and flavanols. Coarse grains contain various flavonoids which are typically found in the pericarp. Peonidin, malvidin, delphinidin, petunidin, cyanidin and pelargonidin are the six most common anthocyanidins located in cereals. Maize consists of petunidin-3-rutinosides, cyanidin-3galactosides, pelargonidin glycosides, cyanidin-3-glucosides, peonidin-3glucosides and cyanidin-3-rutinosides (McDonough et al. 2004; Prior et al. 2005). Sorghum contains a variety of anthocyanidins which includes 7-methoxyluteolinidine, apigenin-5 glucosides, 7-methoxy-5-glucosides, luteolin-5glucosides, apigenin din and 5-methoxyapigeninidin. Sorghum consists of an inimitable member of the anthocyanidin group called 3-deoxyanthocyanidin which is very stable at high $\mathrm{pH}$ and makes sorghum a great food colourant. Barley contains petunidin-3-glucosides, cyanidin, pelargonidin glycosides, delphinidin, cyanidin-3-glucosides. Vitexin, isovitexin, apigenin, tricin and glycosylvitexin are few of the flavones reported in oats. Flavones present in pearl millet are glucosyl vitexin, vitexin and glycovitexin, whereas finger millet contains several flavones such as lucigenin-1tricin,<smiles>O=C(O)c1cc(O)c(O)c(O)c1</smiles>

a) Gallic acid (Hydroxybenzoic acid)<smiles>O=C(O)/C=C/c1ccc(O)cc1</smiles>

d) p-coumaric acid (Hydroxycinnamic acid)<smiles>O=C(O)c1ccc(O)cc1</smiles>

b) p-hydroxybenzoic acid (Hydroxybenzoic acid)<smiles>COc1cc(/C=C/C(=O)O)ccc1O</smiles>

e) Ferulic acid

(Hydroxycinnamic acid)<smiles>COc1cc(C(=O)O)ccc1O</smiles>

c) Vanillic acid

(Hydroxybenzoic acid)<smiles>COc1cc(/C=C/C(=O)O)cc(OC)c1O</smiles>

f) Sinapic acid (Hydroxycinnamic acid)

Fig. 1 Chemical structures of phenolic compounds present in cereal and millet grains 
orientin, isovitexin, valanthin, isoorientin, vitexin and saponin (Subba Rao and Muralikrishna 2002).

Sorghum contains flavones namely kaempferol-3rutinoside-7-glucuronide, eriodyctiol, naringenin and eriodictyol-5glucosides (Dykes and Rooney 2006). Coarse cereals also hold condensed tannins. The main function of these tannins is to protect grains from biodeterioration (Waniska 2000), however, they are also accountable for the astringency of the grain. Tannins possess gastro-protective, cholesterol-lowering, anticarcinogenic and anti-ulcerogenic properties (Dykes and Rooney 2006). Apart from sorghum and barley, the only millet which contains tannins is finger millet (Siwela et al. 2007). But these tannins sometimes have antinutritional properties which makes them undesirable. Oats carry amides of cinnamoyl anthranilic acids. These are known as avenanthramides and have great activity against oxidation and inflammation. Anti-atherogenic properties of oats are well-known because of the presence of these avenanthramides. Oats also contain a class of phytoestrogens which are called lignans. Other than oats, these lignans are also present in wheat and a member of a wheat tribe called rye. Oats contain approximately 8-299 $\mu \mathrm{g} / 100$ of lignan (Buri et al. 2004). When ingested, these are transformed into mammalian lignans and decrease the hormone-dependent cancers (Buri et al. 2004). Bran contains phytosterols which are cholesterol-like compounds. These phytosterols are present in cereals and exist in free forms, function as esters of fatty acids or fused with sugars (mainly glucose) or hydroxycinnamic acids (mostly ferulate). Corn, sorghum and oats contain 70-88 mg/100 g, 46-51 mg/100 g and $35-46 \mathrm{mg} / 100 \mathrm{~g}$ of non-bound phytosterol while barley contains $55-76 \mathrm{mg} / 100 \mathrm{~g}$ respectively (Ostlund Jr. 2002; Piironen et al. 2002).

Furthermore, it has also been reported that phenolic content, form of phenolic compounds along with their proportion and phenolic content coupled by esterification and etherification differs according to the variety of cereal and millet grains. It has been shown that brown varieties of finger millet contain higher phenolic content proportion (1.3-2.3 g\%) as compared to the white varieties of finger millet (0.3-0.5 g\%) (Shahidi and Chandrasekara 2013).

\section{Bioactivities of phenolics in cereals and millets}

The presence of phenolic compounds in food is directly linked with antioxidant potential (Gliwa et al. 2011). Due to the safety issues, natural antioxidants present in foods have gained wide attention in comparison with the artificial or synthetic counterparts. Antioxidant activity of cereal grains are presented via their reducing power, inhibition of reactive oxygen species, free radical scavenging and ferrous chelating properties (Shahidi and
Chandrasekara 2013; Kumari et al. 2019). These antioxidants have shown various important mechanisms which leads to number of advantages and beneficial health outcomes.

\section{Anti-cancerous activity}

Even today, when multiple strategies and technologies have been developed, cancer is a ruling cause of death worldwide. The most affected bunch of people are those belonging to the lower-income group because of unawareness and illiteracy. Many organisations surveyed in different parts of the world and as stated by the World Health Organisation (WHO), approximately 84 million people are likely to die between 2015 and 2025, if left without remedial interventions. Several studies reported that coarse cereals have abundantly present components which have very good potential in mitigating the risk factors linked with various types of cancers such as breast, colon, prostate and other. The anti-carcinogenic potential is a primitive disease-preventative effect of phenolic compounds. This involves inhibiting the commencement and progression of cancer cells by restricting the transformation of normal human cells, the growing lump angiogenesis, and metastasis. Furthermore, phenolic compounds restore the mechanism of tumorcontrolling proteins like p21, p27, phosphatase, p53 and tensin homolog (PTEN) (Anantharaju et al. 2016). Gallic acid has been reported as an anticancer agent in many studies as it significantly reduces the proliferation of different carcinoma cells such as human prostate cancer cells and human leukaemia (HL)-60 (Shahidi and Yeo 2018). Methyl gallate has been known to suppress the growth of human epidermal cancer (A431) skin carcinogenic cells (Kamatham et al. 2015). The anti-cancerous capacity of phenolic acids including $p$-coumaric, vanillic, ferulic and feruloyl-L-arabinose has also been studied in various cell cultures. Ferulic acid has been reported to show the anticarcinogenic activity by regulating the celldivision cycle, disruption, apoptosis of human pancreatic cells (MIA PaCa-2) (Shahidi and Yeo 2018). Eitsuka et al. (2014) reported the symbiotic anticarcinogenic capacity of phenolic acids namely ferulic acid and $\delta$ tocotrienol against the growth and proliferation of different carcinogenic cells. It has been investigated that the collaboration of ferulic acid and $\delta$-tocotrienol presents an effective inhibitory effect on the growth and multiplication of pancreatic cancer (PANC-1), prostate cancer (DU-145), breast cancer in comparison with their separate use. Phenolic extracts present in millet showed anticancer activity against the HT-29 human colon adenocarcinoma cells (Shahidi and Chandrasekara 2013). Janicke et al. (2011) observed a significant protective effect of $p$-coumaric acid against the proliferation of colon cancer cells by hindering the cell cycle process of Caco- 
2 colon cancer cells. Moreover, some flavonoids such as apigenin, troxerutin and myricetin have demonstrated strong anticancer potential. Apigenin presented a radiosensitive effect in human cancer cells in which the tumor cells which are preserved with apigenin displayed a higher rate of radiosenstivity and apoptosis behaviour in comparison with cells which were not treated with apigenin (Watanabe et al. 2007). Additionally, myricetin displayed an excellent anticancer potential in rats with colorectal cancer induced from 1,2-dimethylhydrazine (Nirmala and Ramanathan 2011). According to Kaur et al. (2014), consistent consumption of sorghum is correlated with reducing incidences of oesophageal cancer in several parts of the world. Phenolic content of sorghum is directly correlated with its antioxidant property (Dicko et al. 2005).

\section{Anti-inflammatory activity}

Inflammation is a crucial biotic response to any tissue injury. The response of immune system to any stimuli such as irritation, damage, or infection is the release of pro-inflammatory cytokines (Shahidi and Yeo 2018). Serious adult disorders such as CVDs, joint related disorders, cancer and allergies may results from overproduction of pro-inflammatory cytokines such as interferon tumor necrosis factor alpha (TNF- $\alpha$ ) and interleukin (IL)-1b. Hence, suppressing of overproduction of these pro-inflammatory cytokines is essential to control and prevent these ailments. Phenolic compounds have been widely used to treat inflammation and associated disorders since prehistoric era. Pragasam et al. (2013) studied the anti-inflammatory potential of $p$-coumaric acid by observing the TNF- $\alpha$ expression in synovial tissue of arthritic rats. Strong anti-inflammatory activity was displayed by $p$-coumaric acid as it reduced the inflammatory mediator TNF- $\alpha$ expression. Antiinflammatory potential of ellagic and caffeic acid was also reported by Chao et al. (2010). Both caffeic acids and ellagic acids were fed to mice by mixing it into their regular diet in the ratio of 2.5 and $5.0 \%$. Inculcating these phenolic acids resulted in the reduction of expression of inflammatory mediators. Hämäläinen et al. (2007) studied the anti-inflammatory activities of flavonoids including kaempferol, quercetin, pelargonidin, isorhamnetin as well as genistein. All of these flavonoids listed blocked iNOS protein by inhibiting main transcription factor of iNOS which is $-\kappa B$ (NF-kB).

\section{Antidiabetic activity}

Willett et al. (2002) reported that risk factors related to diabetes tend to get lower in individuals consuming coarse cereals in their diets. These coarse cereals have a great role in weight management as these foods generally contain a very low glycaemic index and thus gives the person consuming them a feeling of fullness and ensures satiety. Various studies suggested that energy-restricted diets based on foods that are low in glycaemic index result in greater weight loss than high-GI food-based diets (Foster-Powell et al. 2002). Individuals with Non-Insulin Dependent Diabetes Mellitus (NIDDM) have shown a considerable decrease in plasma glucose levels on consumption of finger millets-based diets (Shahidi and Chandrasekara 2013). According to Kaur et al. (2014), individuals with NIDDM showed an average increase in insulin and glucose levels. These results were taken when NIDDM suffered subjects were fed with breakfast cereal enriched with $\beta$-glucan. A combination of finger millet and kodo millet displayed a protective effect in Wistar rats against alloxan-induces oxidative stress and hyperglycaemia (Hegde et al. 2005). Chao et al. (2010) examined the effectiveness of caffeic acid and ellagic acid in controlling the diabetic kidney disease in the rat. Continous feed of phenolic acids for 12 weeks suppressed the sorbitol dehydrogenase activity as well as the levels of sorbitol, fructose and urinary glycated albumin. Anti-diabetic potential by lowering the intestinal movement of glucose via S-Glut1 has also been discovered by various polyphenols such as epicatechin, isoflavones, catechin and chlorogenic acid (Shahidi and Yeo 2018). One main therapeutic technique for treating diabetes mellitus is reduction of postprandial hyperglycaemia by inhibiting the enzyme action required for hydrolysis of complex sugars. Hence, amylase and glucosidase inhibitors may be helpful in reducing the postprandial hyperglycaemia which is the initial metabolic irregularity in type 2 diabetes (Shahidi and Yeo 2018).

\section{Anticholesterolemic potential and inhibitory activity against CVDs}

As stated by the WHO in 2010, 18.5 million people died of cardiovascular-related disorders, which accounts for $32 \%$ of deaths worldwide. Coarse grains have cholesterol-lowering properties and acts as an antioxidant and therefore, reduce the risk factors and incidence of Coronary Heart Diseases (CHD). Synergistic potential of phenolics in foxtail and proso millet was displayed in decreasing the level of triacylglycerol and foxtail millet was shown to lower the C-reactive proteins which is an inflammation related disorder in rats suffering from hyperlipidaemia (Shahidi and Chandrasekara 2013). This suggests potential applications of phenolic compounds in finger millet and proso millet in reducing the risk factors associated with CVD. Ferulic acid has been known to lower the prevalence of CVDs and other neurodegenerative diseases (Shahidi and Yeo 2018). Another factor which may help in lowering the incidence of CVDs are dietary antioxidants such as millet phenolics which prevents LDL oxidation (Shahidi and Chandrasekara 2013). It has been reported that millet phenolics displayed a strong inhibitory activity against copper catalysed low- 
density lipoprotein cholesterol oxidation in vitro (Shahidi and Chandrasekara 2013). Flavonoids and anthocyanins present in coarse grains have antioxidant properties whereas phytosterols, policosanols, fibres and $\beta$-glucans have anticholesterolemic properties.

\section{Anti-obesity activity}

Various studies suggested that better body weight management is directly linked with high fibre diets. It was reported that anthocyanidins, which are also stated as an effective metabolic modulator of adipose tissue, displayed an excellent capacity in attenuating obesity, suppressing dysfunction of fat cells, and reducing accumulation of fat in adipose cells (Shahidi and Yeo 2018). Coarse cereals such as oats, barley are rich sources of fibres and hence, provide good satiety value, which further reduce the appetite and therefore, help in better weight management (Kaur et al. 2014).

\section{Antibacterial activity}

Antibacterial or antimicrobial agents kill or inhibit the action of bacteria without damaging adjacent cells and tissues. These polyphenols also have antimicrobial activity (Călinoiu and Vodnar 2018). Phenolic compounds present in the outermost layer of plant organs function as an inhibitory factor for the physical invasion by microbes. It has been reported that phenolic acids including ferulic acid, caffeic acid and $p$-coumaric acid showed antifungal effects (Shahidi and Chandrasekara 2013). Phenolics present in cereal grains inhibits the growth and multiplication of blood-borne hepatitis $C$ virus (HCV) which further leads to liver cirrhosis and hepatocellular carcinoma (HCC) (Shahidi and Yeo 2018). It was also reported that growth of cariogenic and periodontopathic bacteria can be suppressed by gallic acid and various derivatives. Gallic acid and methyl gallate have also shown strong antibacterial activity against Salmonella (Choi et al. 2008). An inhibitory activity of a combination of gallic acid and methyl gallate was stated against herpes viruses (Shahidi and Yeo 2018). Furthermore, phenolic compounds such as tannins, isoflavones and stilbenes showed antibacterial activity against E. coli, Salmonella, Bacillus and Clostridium and showed inhibitory activity against the growth of yeasts and viruses (Alvesalo et al. 2006). Moreover, according to reports by Taguri et al. (2006), approximately 22 polyphenols showed antimicrobial activity against 26 microbial strains.

\section{Beneficial effects of phenolics in cereals and millets on health}

Besides their crucial role in plants, phenolic compounds or polyphenols in our diet provide various beneficial effects on our health (Table 2). However, health benefits of these phenolics present in foods depends on the rate of absorption and bioavailability. It is evolving that phenolic compounds may have much more vital effect in vivo like improving endothelial function, anti-inflammatory properties and cellular signalling (Brglez Mojzer et al. 2016). Polyphenols also contain flavonoids which provide antiinflammatory, gastro-protective, antioxidative, anti-allergic and anticarcinogenic properties (Duodu and Awika 2019). Some studied have also reported that flavones present in pearl millet are goitrogenic (Shahidi and Chandrasekara 2013). Barnyard millet grains contain flavones such as luteolin and tricin. Luteolin and its glycosides showed beneficial activity such as anti-inflammatory, antioxidant and anticancer (Han et al. 2007). Tricin on the other hand is known for its anti-tumor property as well as it antileukemic activity (Shahidi and Chandrasekara 2013). Lignans also comes under the category of polyphenolic compounds. Mammalian lignans are unique and beneficial in promoting health and fighting against various chronic degenerative diseases because of strong antioxidant activity (Gani et al. 2012). Phytic acid is also considered to be a very strong antioxidant in vitro. Because of the ability of phytic acid to chelate free $\mathrm{Fe}$, it terminates the Fe catalysed oxidative reactions (Gani et al. 2012). Phytic acid also has the ability to overpower lipid peroxidation. It also prevents renal stone development in the body by inhibiting the formation of crystals of calcium oxalate salts in the urine (Gani et al. 2012; Liu 2013). Various phenolic acids such as vanillic, ferulic, quercetin, gallic and $p$-coumaric acids have been reported to be responsible for suppressing cataract of the eye lens (Shahidi and Chandrasekara 2013).

\section{Bioavailability of bioactive active compounds in cereals and millets}

Prospective absorption of an element can be determined by measuring the amount of that element when passes via cell membranes in the intestinal area and is present for activity inside the cells (Kumari et al. 2019). Bioavailability is defined as the quantity of compound which is released from a solid food mixture into the gut (Shahidi and Peng 2018). Phenolic compounds present in foods undergo various levels due to digestion in the gastric and intestinal phases (Kumari et al. 2019). The remains after the intestinal digestion enter colon and go through fermentation process with the help of bacterial enzymes that are responsible for the release of bound phenolics. In the large intestine, phenolic acids that exists in free form may apply their bioactivity on-site or by bio converting into colonic metabolites on the epithelium-site (Kumari et al. 2019). Stomach, colon and intestinal lumen have the ability to recollect significant quantities of unabsorbed phenolics from food which may play a vital role in protecting gastrointestinal tract (GIT) from oxidative stress (Jenner et al. 2005). Unabsorbed 
Table 2 Bioactivities of phenolic acids and flavonoids in different cereal and millet grains

\begin{tabular}{|c|c|c|c|}
\hline Grains & Phenolic compound & Bioactivities & References \\
\hline & Phenolic acids & & \\
\hline $\begin{array}{l}\text { Cereals } \\
\text { Barley, sorghum, wheat, rice, oats, } \\
\text { maize, } \\
\text { Millets } \\
\text { Finger, pearl and foxtail millet }\end{array}$ & Ferulic acid & $\begin{array}{l}\text { Anti-carcinogenic } \\
\text { Prevents and controls type } 2 \text { diabetes } \\
\text { Suppressing hypertension }\end{array}$ & $\begin{array}{l}\text { Fahrioğlu et al. (2016) } \\
\text { Narasimhan et al. (2015) } \\
\text { Hou et al. (2004) } \\
\text { Kaur et al. (2014) }\end{array}$ \\
\hline $\begin{array}{l}\text { Cereals } \\
\text { Sorghum, rice } \\
\text { Millets } \\
\text { Finger millet }\end{array}$ & Gallic acid & $\begin{array}{l}\text { Anti-cancer } \\
\text { Antimicrobial }\end{array}$ & $\begin{array}{l}\text { Yeh et al. (2011) } \\
\text { Kang et al. (2008) } \\
\text { Kaur et al. (2014) }\end{array}$ \\
\hline $\begin{array}{l}\text { Cereals } \\
\text { Barley, maize, oats, rice, sorghum } \\
\text { Millets } \\
\text { Finger, pearl and foxtail millet }\end{array}$ & p-coumaric acid & Anti-cancer & $\begin{array}{l}\text { Janicke et al. (2011) } \\
\text { Kaur et al. (2014) } \\
\text { Dykes and Rooney (2007) }\end{array}$ \\
\hline $\begin{array}{l}\text { Cereals } \\
\text { Maize, oats, rice, sorghum, wheat } \\
\text { Millets } \\
\text { Finger, pearl and foxtail millet }\end{array}$ & $\begin{array}{l}\text { Chlorogenic and caffeic } \\
\text { acids }\end{array}$ & Anti-carcinogenic and anti-mutagenic & $\begin{array}{l}\text { Mennen et al. (2005) } \\
\text { Kaur et al. (2014) } \\
\text { Dykes and Rooney (2007) }\end{array}$ \\
\hline \multirow[t]{2}{*}{$\begin{array}{l}\text { Cereals } \\
\text { Maize, oats, rice, sorghum, wheat, } \\
\text { barley } \\
\text { Millets } \\
\text { Finger and pearl millet }\end{array}$} & Vanillic acid & $\begin{array}{l}\text { Anti-inflammatory } \\
\text { Antioxidant }\end{array}$ & $\begin{array}{l}\text { Calixto-Campos et al. (2015) } \\
\text { Dykes and Rooney (2007) }\end{array}$ \\
\hline & Flavonoids & & \\
\hline $\begin{array}{l}\text { Cereals } \\
\text { Oats, sorghum } \\
\text { Millets } \\
\text { Finger millet }\end{array}$ & Apigenin & $\begin{array}{l}\text { Anti-inflammatory } \\
\text { Anti-cancer }\end{array}$ & $\begin{array}{l}\text { Ju et al. (2015) } \\
\text { Watanabe et al. (2007) } \\
\text { Dykes and Rooney (2007) }\end{array}$ \\
\hline $\begin{array}{l}\text { Cereals } \\
\text { Maize, oats }\end{array}$ & Kaempferol & $\begin{array}{l}\text { Anti-inflammatory } \\
\text { Anti-cancer }\end{array}$ & $\begin{array}{l}\text { Calderon-Montano et al. } \\
\text { (2011) } \\
\text { Devi et al. (2015) } \\
\text { Kaur et al. (2014) }\end{array}$ \\
\hline $\begin{array}{l}\text { Cereals } \\
\text { Barley and sorghum }\end{array}$ & Catechin & $\begin{array}{l}\text { Preventing Parkinson's and Alzheimer's } \\
\text { diseases }\end{array}$ & $\begin{array}{l}\text { Dai et al. (2006) } \\
\text { Kaur et al. (2014) } \\
\text { Shahidi and Yeo (2018) }\end{array}$ \\
\hline $\begin{array}{l}\text { Cereals } \\
\text { Oats, wheat } \\
\text { Millets } \\
\text { Barnyard millet }\end{array}$ & Tricin & $\begin{array}{l}\text { Anti-obesity } \\
\text { Anti-inflammatory }\end{array}$ & $\begin{array}{l}\text { Lee and Imm (2017, 2018) } \\
\text { Dykes and Rooney (2007) }\end{array}$ \\
\hline $\begin{array}{l}\text { Cereals } \\
\text { Oats, sorghum } \\
\text { Millets } \\
\text { Foxtail and Barnyard millet }\end{array}$ & Luteolin & $\begin{array}{l}\text { Antioxidant } \\
\text { Anti-inflammatory }\end{array}$ & $\begin{array}{l}\text { Pradeep and Sreerama (2018) } \\
\text { Dykes and Rooney (2007) }\end{array}$ \\
\hline
\end{tabular}

phenolic compounds also play a crucial role in reducing the risk factors associated with gastric, rectal and colon cancers (Jenner et al. 2005).

\section{Antinutritional factors}

Coarse grains contain various antinutrient factors that restrict their nutritive value. Phytic acid, tannins and enzyme inhibitors are the main antinutrients present in coarse cereals.

\section{Phytates}

Phytates, also referred to as phytic acids, are generally present in the plant organs naturally. The amount of phytic acid in these cereals are about $825.7 \mathrm{mg} / 100 \mathrm{~g}$ (ElMaki et al. 2007). According to various reports, phytates are known to hinder the enzyme activity which is essential for degradation of protein in the stomach and small intestine (Kies et al. 2006). It was also reported that phytates generally affect the bioavailability of various minerals. Phytic acid have been reported to have a strong effect on new-borns, pregnant and lactating women when large portions of cereal-based foods are consumed (Al Hasan et al. 2016). Due to negativelycharged structure, phytic acid generally attracts and binds to the positively-charged ions such as calcium, zinc, iron and magnesium to form complexes and lowers 
the bioavailability of these metal ions. Primarily because of this chelating property of phytates, they are viewed as the most effectual anti-nutrient and a reason for minerals related deficiencies in both human and animal diets (Grases et al. 2017).

\section{Tannins}

Tannins comes under the category of phenolic compounds. The major property of tannins is that they can precipitate proteins. Tannins are considered to be secondary compounds and are generally formed in fruits, bark and leaves of the plant (Timotheo and Lauer 2018). Tannins usually form reversible and permanent tanninprotein complexes between the hydroxyl group of tannins and carbonyl group of proteins which further affects digestibility of proteins and leads to depletion of essential amino acids (Raes et al. 2014). There are two types of tannin groups in nature: hydrolysable and condensed. Peanuts and millets hold condensed tannins in plenty amounts (Chandrasekara and Shahidi 2011). Hydrolysable type of tannins is promptly broken down in ruminants during the digestion process. It was also reported that these breakdown products may contain a lot of compounds which can be toxic in nature. On ingestion, tannins make complexes with protein which can further cause inhibition in the activity of many digestive enzymes (Joye 2019).

\section{Enzyme inhibitors}

Proteinases are those enzymes which play a vital role in enhancing overall nutritional and functional properties of different protein molecules (Salas et al. 2018). Number of proteolytic activities are completed by proteases inhibitors (PIs). Cereal grains mostly comprised of plant serpins which is one of the biggest PIs family. These serpins are also knowns suicide inhibitors and are also found in various other species in plant kingdom. Serpins are known to have effective inhibition activity. It generally inhibits activities of trypsin and chymotrypsin by attacking the most reactive sites of enzymes. PIs are considered as natural inhibitors and over the years have become a significant research topic because of their active way of inhibiting enzymatic activity with the help of forming protein-protein based complexes. These PIs limit the enzymatic activity by blocking the most active site of enzyme via catalytic mode. The two main types of PIs are Bowman-Birk inhibitor and Kunitz trypsin inhibitor. There are many enzyme inhibitors in plant-based foods but those inhibitors that affect both trypsin and $\alpha$-amylase activities are present in almost all cereal grains and cereal-based foods. $\alpha$-amylase chiefly controls the breakdown of complex carbohydrates into simpler ones. Hence, those enzyme inhibitors that particularly inhibit the activity of $\alpha$-amylase will lead to delay in carbohydrate digestion and absorption. Rise in carbohydrate digestion time further results in reduction in the rate of glucose absorption which directly affects the normal postprandial blood glucose level. Trypsin inhibitors when occurs in human diets results in reduced growth rate due to decreased digestion of proteins and amino acids accessibility also leading to pancreatic problems (Adeyemo and Onilude 2013).

\section{Effect of germination on antinutrients in coarse cereals and millets}

Nutrient availability of coarse cereals can be improved by a simple traditional food processing operation called as malting/germination (Subba Rao and Muralikrishna 2002; Hejazi et al. 2016). With the help of this in vivo biotransformation process, hydrolytic enzymes improve drastically, which further enhances the bioavailability of vitamins, carbohydrates, minerals and proteins (Hejazi et al. 2016). In the presence of boiled water or milk, the amylases present in the malted flour hydrolyse starch into sugars which further leads to good taste, nutrientdense and low bulk slurry that can be utilised as weaning food (Hejazi et al. 2016). The two main factors to observe throughout the germination process is germination duration and temperature. These two factors greatly influence the nutritional improvement of cereal grains (Narukawa et al. 2012; Sawant et al. 2012). In addition to all the benefits listed above, germination is also known as one of the most effective method for lowering the anti-nutrients of cereals grains (Nkhata et al. 2018). When seeds undergo germination, it leads to the activation of enzyme phytase which further reduces phytate and leads to reduced phytic acid levels. Germination generally affects the physical structure, nutritional composition and biochemical activity of foods. Germination results is lowering the concentration of various strong anti-nutrients like tannin and phytic acid which directly increases the bioavailability of various minerals in the body and hence results in improved nutritional value of food product (Oghbaei and Prakash 2016). It was also reported that maximum decrease in antinutrient content was noted when millets undergone germination as compared to other methods such as soaking, fermentation and milling (Singh et al. 2017). According to a study by Abioye et al. (2018) phytate level in finger millet keeps decreasing when germination duration increases. A reduction in tannin content in sorghum is also reported, which is ascribed to leaking in the malting medium (Singh et al. 2015). An increase of polyphenol oxidase activity and various other catabolic enzymes were noticed on germination (Singh et al. 2015). 


\section{Effect of probiotic fermentation on antinutrients in coarse cereals \& millets}

Coarse cereals and millets play a very crucial role in human diets. The combination of cereals with other methods result in better nutrient profile and an enhanced amino acid pattern. However, the chief hindering factor in the bioavailability of coarse cereals are the high amount of antinutrients and inhibitors. Likewise, tannins and phytic acid are also known to hamper the activity of amylolysis and proteolysis (Peyer et al. 2016). Several methods and combination of methods is known to decrease the antinutrient content. Fermentation is said to be the most crucial and popular process which considerably lowers the antinutrients content and hence, enhance the overall nutritive value of coarse cereals and other food grains. Fermentation of cereals is a primaeval and economical food preservation method. In most of the developing countries, within the aboriginal communities, fermenting cereals is a traditional and regular practice (Blandino et al. 2003). Fermentation aids in the multiplication of selected microorganisms and their metabolic-related activities in food. Fermentation not only enhances the nutritional value but also improves the digestibility of raw products. It improves the sensory characteristics and also enhances the functional qualities of foods and beverages (Blandino et al. 2003). Such type of food or food product would be beneficial for all the age groups including children, adults and senior citizens. This type of food mixture can be consumed by a large group of the vegetarian population of the developing countries. Due to many issues like lactose intolerance, vegetarianism among the population and costly dairy products, the concept of combination of probiotic and coarse cereals was developed (Coda et al. 2010). Cereal grains have the capability to provide probiotic, prebiotic as well as general whole cereal benefits (Lamsal and Faubion 2009). Many researchers suggested that probiotic yeasts have the perfect characteristics to be developed as probiotic and cereal-based functional product. Yeasts have the capability to maintain its viability and stability when food processing conditions changes (Peyer et al. 2016). Yeasts can tolerate a wide variety of salt concentration, pH and oxygen activity (Arroyo-López et al. 2008; Bonatsou et al. 2015). Many researchers concluded that fermentation of coarse cereals and millets with probiotics significantly impact the antinutrients content (Table 3). Sindhu and Khetarpaul (2001) reported that fermentation with different probiotics resulted in further reduction in the antinutrient contents. It was reported that when millet was subjected to fermentation for 12 and $24 \mathrm{~h}$, various anti-nutrients such as PIs, phytic acid and tannins were reduced (Coulibaly et al. 2011). In a recent study, to examine the effect of fermentation on anti-nutritional activity, maize flour was undergone fermentation with a consortium of Lactic Acid Bacteria (LAB) with $12 \mathrm{~h}$ intervals in between. The results displayed that with increase in fermentation time, considerable deduction in antinutrients were noticed in fermented maize flour (Chibuike Ogodo et al. 2014). Fermentation performed with single cultures of $L$. casei and $L$. plantarum showed a decreasing trend in phytic acid by about 66 and $64 \%$ respectively. However, when a combination of these cultures was used for fermenting the food mixture, a complete elimination of phytic acid was observed (Sindhu and Khetarpaul 2001). Polyphenol content decreased by $31 \%$ after combination culture fermentation with S. boulardii and L. plantarum (Sindhu and Khetarpaul 2001). No trypsin inhibitor activity was found neither in single nor in sequential fermentation (Sindhu and Khetarpaul 2001).

Table 3 Nutritional and functional effects of different probiotic strains on cereals and millets (Verni et al. 2019)

\begin{tabular}{|c|c|}
\hline Probiotic strain & Effect \\
\hline Lactobacillus plantarum LB1 & $\begin{array}{l}\text { Increase antioxidant activity } \\
\text { Increase phenolic content } \\
\text { Decrease anti-nutritional factors }\end{array}$ \\
\hline Lactobacillus brevis & $\begin{array}{l}\text { High fibre solubility } \\
\text { Increase peptide and free amino acid content }\end{array}$ \\
\hline Lactobacillus bulgaricus & $\begin{array}{l}\text { High fibre solubility } \\
\text { Increase peptide and free amino acid content }\end{array}$ \\
\hline Lactobacillus rhamnosus GR1 & $\begin{array}{l}\text { Increase folic acid } \\
\text { High fibre solubility }\end{array}$ \\
\hline Saccharomyces cerevisiae & $\begin{array}{l}\text { Anti-stress } \\
\text { Anti-fatigue } \\
\text { Anticancer }\end{array}$ \\
\hline Bacillus subtilis & Antioxidant \\
\hline Debaryomyces hansenii & Production of phenolics and xylitol \\
\hline Lactobacillus reuteri & Increase of gamma-linolenic acid and $\beta$-carotene \\
\hline
\end{tabular}




\section{Effect of germinating and non-germinating seeds on $\mathrm{pH}$, acidity, cell count and proximate composition in cereal foods}

According to Kaur et al. (2014), due to germination, the titratable acidity of coarse cereals tends to increase and thus there is a considerable reduction in $\mathrm{pH}$ of these germinated samples. While, on the other side, the samples which doesn't undergo germination has lesser titratable acidity and hence higher $\mathrm{pH}$. The decrease in $\mathrm{pH}$ during germination maybe because of hydrolysis of starch into sugars, which is promptly used by the organisms and converted into lactic acid. Germinated cereal based food products have higher cell count and better growth of bacteria as compared with the nongerminating cereal-based food product (Arora et al. 2010). The reason for higher cell count may be resulted from hydrolysation of flours that undergone germination as this further provides media with a better environment for the optimum growth of these organisms. The moisture, ash and fat content of germinated and nongerminated food mixtures did not differ considerably (Arora et al. 2009). The protein and fibre values of food mixture containing germinated cereal flour are notably lower in comparison with the food product developed from non-germinated cereal flour. Similarly, according to the results, Hejazi et al. (2016) also reported an enhancement in protein extractability and reduction in the amount of total protein in germinated finger millet. Elkhalifa and Bernhardt (2010) noted a considerable increase in the nitrogen solubility index of sorghum which might be because of the steady breakdown of stored protein into amino acids and short length peptides caused by rising the concentration of protease enzymes. This further results in increase in the overall nutritive value of germinated sorghum grains by gradually increasing its protein digestibility and hence, partially hydrolysed reserve proteins may be more easily accessible for pepsin attack. This result implies that flour made from the germinated sorghum would be excellent firming agent and would be beneficial in food products such as pie and dishes which involve thickening or gelling properties as germination leads to denaturation of proteins which further results in more aggregation. Food mixture which was subjected to germination has better thiamine and niacin content as compared to the food mixture which was not germinated (Hejazi et al. 2016). It was also reported that germination was found to be effective in increasing the $\mathrm{HCl}$ extractability of various minerals including calcium and iron. Extractability of iron and calcium increased from 18.1 and $76.9 \%$ in raw finger millet to 37.3 and $90.2 \%$, respectively whereas extractability of a trace element like zinc when germinated increased from 65.3 to $85.8 \%$ which was due to reduction in phytic acid content from 0.36 to $0.02 \mathrm{~g} / 100 \mathrm{~g}$ dry matter (Mbithi-Mwikya et al. 2000). According to Arora et al. (2009), the concentration of thiamine and niacin content after germination was almost doubled. Germinated food mixture contained notably higher lysine content in comparison with food mixture which was not germinated (Arora et al. 2009). According to Hejazi et al. (2016), during germination, there was a prompt rise in total free amino acids by about $4-6$ folds. The starch content decreased significantly in germinated food mixture in comparison with the food mixture which is not germinated. This may be because germination leads to the enzymatic hydrolysis which results in the conversion of starch into simpler sugars. The concentration of both types of sugar: reducing and nonreducing indicated a rising trend in germinated based food in comparison with non-germinating food. On the other side, food mixture developed from germinated flour has significantly lower total, soluble and insoluble dietary fibre contents in comparison with the food mixture formulated flour which was not germinated (Arora et al. 2009). It might be because of the fact that germination caused a considerable decrease in all the dietary fibre components. Germinated cereals contain an enzyme called b-galactosidase which partly attacks galactomannan to form galactose. Thus, the reduction in the polysaccharide and mucilage concentration might be ascribed to their disintegration and utilisation by the growing sprouts (Hooda and Jood 2003). Due to the breakdown of high molecular weight polymers in the process of germination, the cereal grains often lead to grouping of bio-functional substances and the enhancement of the organoleptic properties because of the softening of texture and improvement of flavour in barley, finger millet and oats (Subba Rao and Muralikrishna 2002).

\section{Effect of probiotic fermentation on $\mathrm{pH}$, nutrient composition and volatile compounds in cereal- based foods}

Those samples which contain coarse cereals and millets when subjected to probiotic fermentation results in a considerable reduction in $\mathrm{pH}$ and rise in titratable acidity. Such type of trend was commonly reported when a variety of foods including cereal-based mixture and finger millet undergoes lactic acid fermentation (Sindhu and Khetarpaul 2001). According to Sindhu and Khetarpaul (2001), the most effective bacteria in lowering $\mathrm{pH}$ other than yeast is Lactobacillus spp. The moisture, ash and fat contents of food mixtures after fermentation with probiotics did not vary considerably (Sindhu and Khetarpaul 2001). Crude protein and crude fibre contents of food mixture decreased considerably after probiotic fermentation. It was reported that fermentation of food causes the solubilisation of fibre which indirectly 
results in a reduction in crude fibre content (Arora et al. 2010). Many researchers also reported that fermenting natto and tempeh results in a notable rise in free amino acids content (Nassar et al. 2008). This can be due to the fact that throughout the fermentation process, microbes release various hydrolytic enzymes which are responsible for the conversion of complex proteins into simpler proteins (Nassar et al. 2008). Likewise, increased protein content due to fermentation has also been reported in millets (Elkhalifa et al. 2007). Additionally, Fermentation has also known to increase the nutritional composition of various cereal grains by increasing such as tryptophan, lysine and methionine (Mohapatra et al. 2019). As far as B complex vitamins are concerned, cereal-based food mixture which was fermented with probiotic strain resulted in enhancement of thiamine and niacin contents. Similarly, Arora et al. (2010) reported that when pearl millet was fermented with $L$. acidophilus, there was an insignificant rise in thiamine content but when fermentation of pearl millet was done with the help of Saccharomyces cerevisiae and Saccharomyces diastaticus, thiamine content was almost doubled up. When the cereal-based food mixture fermented with L. acidophilus, it caused a considerable increase in lysine content (Arora et al. 2010). Likewise, Elkhalifa et al. (2007) showed that fermentation causes a significant increase in lysine and methionine concentration. This is in agreement with the other findings which shows that fermentation causes an increase in lysine content and overall availability. Hassan et al. (2006) reported that the content of total free amino acids showed a rapid increase of about 3-5 folds when subjected to germination and this amount doubles up when subjected to fermentation (Fig. 2). However, on fermenting with the probiotic organism, starch content was notably decreased. This caused a rise in content of reducing sugar and a corresponding decrease in total soluble and non-reducing sugar contents. Lower starch content in fermented food product may result from fermenting microbes which causes the hydrolysis of polysaccharides (Sindhu and Khetarpaul 2001). Fermented mixtures contain soluble sugars which are used by the microflora as a source of carbon and the fermented food product may eventually contain a lower amount of sugars. According to various researches, in the starting of the fermentation process, levels of sugars seems to be higher, but as the fermentation progresses, the levels of sugars show a downward trend. This is because of the prolonged period of fermentation which leads to utilization of sugar by the fermenting microflora. The considerable reduction was also observed in total and insoluble dietary fibre and improvement in soluble fibre of fermented cereal-based food mixture, due to increased activity of hydrolysing microbial enzymes. Cereals contain some indigestible oligosaccharides such as stachyose, verbascose, and raffinose which further results in flatulence

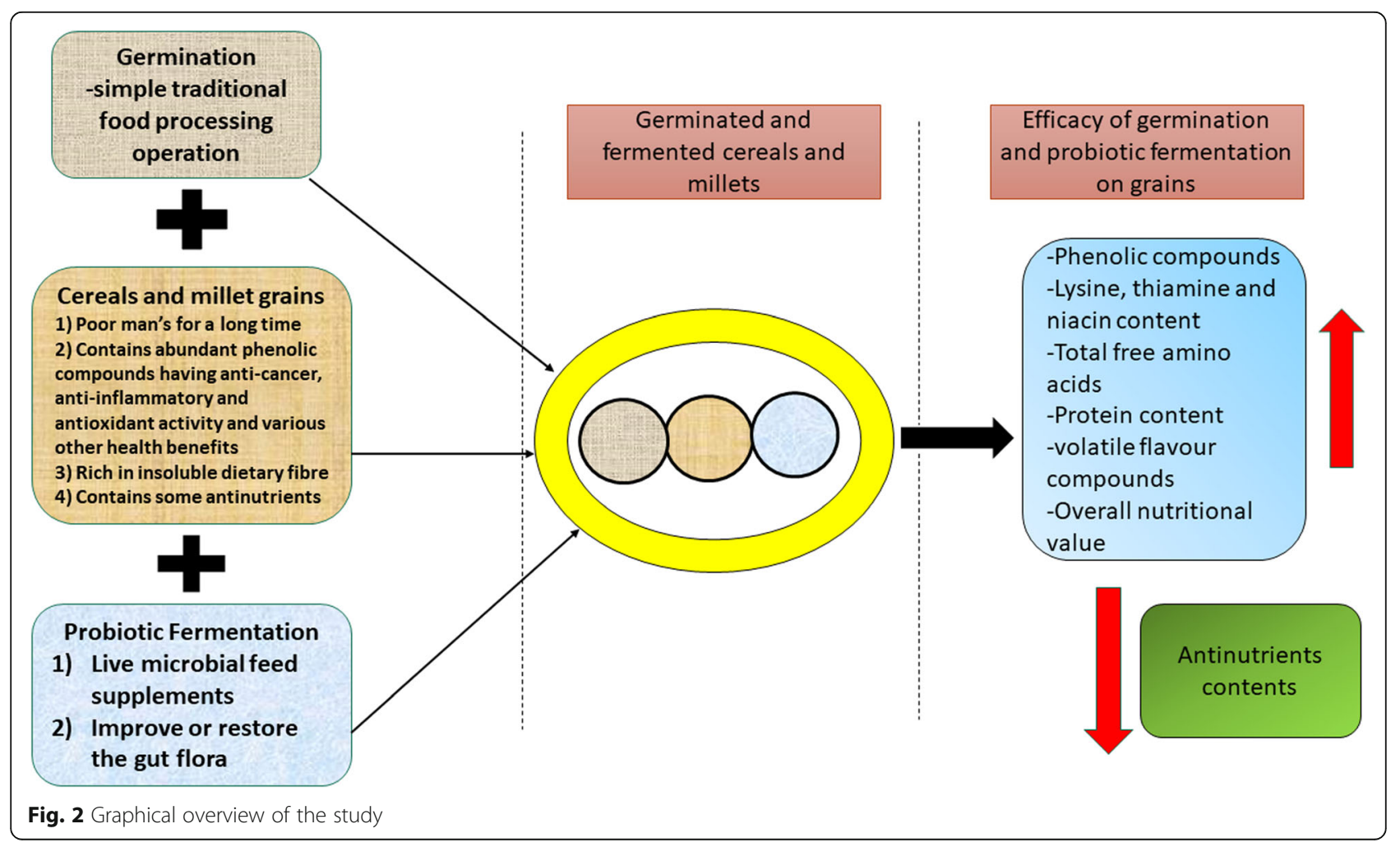


in stomach, diarrhoea and digestion problems. These types of sugars have some $\alpha$-Dgalactosidic bonds which are somewhat heat resistant. These bonds can be devalued by some LAB including strains of L. fermentum, L. plantarum, L. salivarius, L. brevis, L. buchneri and L. cellobiose as these strains include galactosidase enzymes (Holzapfel 2002). During the process of fermentation, these microbes completely disintegrate these oligosaccharides and convert them into beneficial di- and mono-saccharides (Leroy and De Vuyst 2004). Fermentation in cereal grains also leads to release of various bioactive compounds by structural break down of cereal cell wall (Liukkonen et al. 2003). When already germinated rye was subjected to fermentation, there was a rapid increase in the levels of phenolic compounds, lignans and folates (Singh et al. 2015). The folate levels were improved up to seven-fold and that of phenolic compounds up to ten-fold after undergoing both germination and fermentation.

Ogunremi et al. (2015) reported that probiotic strain Pichia kudriavzevii OG32 when added in the cereal-based food mixture enhanced the formation of volatile flavour compounds in the fermented product.

\section{Role of cereals in synbiotics}

The significance in using articulations of prebiotics and probiotics appeared when it was found out that these components have the ability to enhance the intestinal homeostasis and overall health of the individual (host) (Pandey et al. 2015). The combination of synbiotics and cereals can do wonders in improving overall health and bioavailability of various vitamins and minerals in the body. Salmerón (2017) also suggested the potential application of synbiotics in modulating lipid metabolism by controlling blood lipid levels during in vivo tests of Lactobacillus acidophilus based fermented rice bran. Synbiotics alter the intestinal microbiota and enhance the microbes-based interactions with the immune system. The concept of synbiotics have the encouraging ability to be utilised in the connection between gut and brain and also have the potential in dealing and treating autism (Dar et al. 2017).

\section{Fermented foods based on coarse cereals and millets in the market \\ Boza}

Boza is a popular fermented food product in the Balkan countries of region naming Turkey, Romania, Bulgaria and Albania (Nyanzi and Jooste 2012). It is a traditional highly viscous product and includes ingredients such as millet, wheat, rice, maize, rye and other cereals mixed with sucrose. Boza is very famous for its pleasant taste, unique flavour and overall nutritional value. Unconstrained fermentation involves LAB and yeasts (Nyanzi and Jooste 2012). There are various $\mathrm{LAB}$ species isolated from Boza includes $L$. mesenteroides subsp. Mesenteroides, L. oenus, L. brevis, L. mesenteroides subsp. Dextranicum, L. fermentum, $L$. raffinolactis, L. plantarum, L. coryniformis, L. sanfrancisco and L. coprophilous.

\section{Kvass}

Kvass is a popular non-alcoholic fermented cereal-based beverage mainly consumed in Eastern Europe. This beverage is made from sucrose, rye flour, rye and barley malt and stale rye bread. It is manufactured with the help of two methods. The first method involves the hydrolysation of gelatinised starch by the utilisation of malt enzymes, while the second technique includes the utilisation of stale dough bread in which sugars are obtained for the fermentation of yeasts with the help of bread-making process (Nyanzi and Jooste 2012). Various microorganisms found in kvass are L. casei, L. mesenteroides and S. cerevisiae.

\section{Koko}

Koko is impulsively fermented beverage based on millets. This sort of beverage is chiefly consumed in Northern Ghana. Microbial species found in Koko during fermentation are L. fermentum and Weissella confuse. Many studies reported that strains isolated from Koko showed tolerance against 0.3 ox gall bite, great antimicrobial activity, resistance against acids at $\mathrm{pH} 2.5$ (Nyanzi and Jooste 2012). These are the features of excellent and fine quality probiotic strains.

\section{Proviva}

Proviva is popular to be the first oats-based probiotic beverage. It has been very popular in Sweden since 1995. Malted barley in proviva functions as a liquefying agent. The predominant microorganism in Proviva is L. plantarum. A mixture of fruit juice and $4 \%$ oatmeal having a probiotic bacterial count of $5 \times 10^{10} \mathrm{CFU} / \mathrm{L}$ (Nyanzi and Jooste 2012).

\section{Fermented foods based on coarse cereals and millets developed}

Barley, Coprecipitate, green gram and tomatoes (BCGT) food mixture (Sindhu and Khetarpaul 2001)

Aboriginally formed BCGT food product contains sprouted green gram slurry, barley-based flour, tomato pulp and milk precipitate (1:2:1:1 w/w). This type of food mixture was inoculated with $2 \%$ culture in liquid form. Two types of fermentation were done, i.e., single culture-based fermentation and sequential culture-based fermentation. Microorganisms mainly used are $S$. boulardii, L. plantarum and $L$. casei. Both types of fermentation techniques significantly decreased the phytic acid, trypsin inhibitor activity and tannic acid content 
while correspondingly enhancing the in vitro starch and protein digestibility.

Millet based probiotic yoghurt (Di Stefano et al. 2017) Probiotic yoghurt has been developed by using a pure culture of Lactobacillus rhamnosus GR-1 and Streptococcus thermophilus C106. This probiotic yoghurt developed contains fiti sachet. It has gained wide acceptance in the developing countries to reduce the incidence and risk factors associated with malnutrition and other nutrition-related disorders. The main aim of this study was to analyse the fermenting ability of millet on the addition of fiti sachet consortium. Fermentation of millet was proved to be advantageous as many organic acids were quantified, especially phytic acid, which was observed to be decreasing when fermentation time increases, hence, this results in the improvement in bioavailability of particular micronutrients.

\section{Cereal mix -based probiotic functional food (Ogunremi et al. 2015)}

A cereal mix containing pearl millet, white sorghum, red sorghum and wheat was undergone fermentation with probiotic strain Pichia kudriavzevii OG32. This probiotic strain enhanced the viscosity of cereal mixture prepared with the inoculum size of $1.84 \times 10^{5} \mathrm{CFU} / \mathrm{ml}$ and simultaneously giving the highest viscosity of $1793.6 \mathrm{mPa}$. A total of forty volatile compounds were found in cereal mix based fermented food product, while esters and acids were considered to be in the largest percentage. This product scavenged 2,2-diphenylpicrylhydrazyl (DPPH) activity from a methanolic solution by $55.71 \%$. Probiotic yeast used here enhanced the organoleptic and functional properties of the cereal-based mixture during the fermentation process.

\section{Pearl millet-based food blend (Arora et al. 2010)}

This type of food blend was prepared by mixing germinated pearl millet flour, whey powder and tomato pulp $(2: 1: 1 \mathrm{w} / \mathrm{w})$. Adding whey powder and tomato pulp not only improved the nutrient content of food mixture but also provided a perfect medium for the growth of probiotic L. acidophilus. Probiotic fermentation in pearl millet also enhanced the bioavailability of calcium, zinc and iron. Hence, pearl millet-based food blend provides unique nutritional and therapeutic value.

\section{Finger millet and oats based synbiotic drinks (Dar et al. 2017)}

A synbiotic drink was developed using finger millet, oats and double toned milk. Malt drink with the ratio of 60 : 40 (finger millets: oats) with three times of water was finalised based on the sensory evaluation conducted. The ratio of 47:53 (malt drink: double toned milk) was finalised and selected. To further improve the nutritional and functional properties, rose syrup and marigold powder was added for flavour. The prepared drink was higher in carbohydrates, energy content, total solids and minerals, while it was low in lactose, cholesterol and fat in comparison with dairy milk. The composite drink was rich in healthy components such as anthocyanins, betaglucan and soluble dietary fibre, these components are otherwise absent in dairy milk. This drink proves to be a good prebiotic due to the presence of dietary fibre.

\section{Conclusion}

This review is about the aptness of coarse cereals and millets as viable delivery vehicle for probiotic-based fermentation to develop a functional cereal-based probiotic product (Fig. 2). The formulation of functional fermented coarse cereals-based food products in association with specific probiotic microbial strain meets the ongoing demand for healthier, nutritional, functional and diversified foods. It may be concluded that association of germination along with probiotic fermentation of an indigenously formulated cereal-based food blend is a potential application for developing products with improved and better nutritional quality. Such type of fermented food blends not only provides distinctive nutritional and therapeutic value but also are safe for human consumption. Fermentation with probiotic has an effect on sensory and functional characteristics of cereal-based slurry. It can be concluded that with the incorporation of probiotic strain in the cereal-based food product, the bioactivity of various phenolic acids increases and there are improvements in flavour, colour and overall quality of the product. Therefore, from nutritional outlook, especifically for people who consume less vegetables and fruits than the daily recommended intake. Lastly, coarse cereals-based foods and beverages can be benificial for health and to be used like prebiotics and probiotics. Although, it is crucial to note several challenges associated with coarse cereals grains and how they may evade in enhancing probiotic cereal food product delivery to the target population.

\section{Future aspects and recommendations}

The utilisation of a huge range of cereal substrates fermented with single or sequential probiotic microbial cultures can be found out with under-utilised and unpopular coarse cereals in association with different microbial strains and under different conditions. To substantiate such therapeutic and functional claims, preclinical and clinical trials can be done. The utilisation of probiotic microbial cultures in association with coarse cereals and millets has to be done on a number of discussions such as pathogen inhibitory capabilities, functional and technological properties. 


\section{Abbreviations}

LAB: Lactic Acid Bacteria; CVD: Cardiovascular diseases; PIs: Protease inhibitors; TNF: Tumor necrosis factor; WHO: World Health Organisation; NIDDM: Non-Insulin Dependent Diabetes Mellitus; BCGT: Barley, Coprecipitate, Green gram and Tomatoes; NCDs: non-communicable diseases

\section{Acknowledgements}

None.

\section{Authors' contributions}

Savita Budhwar: Conceptualization, Validation and Supervision. Kashika Sethi: Literature Search, Writing- Original Draft, Writing- Reviewing and Editing. Manali Chakraborty: Editing. The authors read and approved the final manuscript.

\section{Funding}

Not applicable.

\section{Availability of data and materials}

The datasets used and/or analysed during the current study are available from the corresponding author on request.

\section{Competing interests}

None.

Received: 20 March 2020 Accepted: 4 May 2020

Published online: 01 June 2020

\section{References}

Abioye, V., Ogunlakin, G., \& Taiwo, G. (2018). Effect of germination on anti-oxidant activity, total phenols, flavonoids and anti-nutritional content of finger millet flour. Journal of Food Processing \& Technology, 9, 719.

Adeyemo, S., \& Onilude, A. (2013). Enzymatic reduction of anti-nutritional factors in fermenting soybeans by lactobacillus plantarum isolates from fermenting cereals. Nigerian Food Journal, 31(2), 84-90.

Agil, R., \& Hosseinian, F. (2012). Dual functionality of triticale as a novel dietary source of prebiotics with antioxidant activity in fermented dairy products. Plant Foods for Human Nutrition, 67(1), 88-93.

Al Hasan, S. M., Hassan, M., Saha, S., Islam, M., Billah, M., \& Islam, S. (2016). Dietary phytate intake inhibits the bioavailability of iron and calcium in the diets of pregnant women in rural Bangladesh: A cross-sectional study. BMC Nutrition, 2(1), 24.

Alvesalo, J., Vuorela, H., Tammela, P., Leinonen, M., Saikku, P., \& Vuorela, P. (2006). Inhibitory effect of dietary phenolic compounds on chlamydia pneumoniae in cell cultures. Biochemical Pharmacology, 71(6), 735-741.

Anantharaju, P. G., Gowda, P. C., Vimalambike, M. G., \& Madhunapantula, S. V. (2016). An overview on the role of dietary phenolics for the treatment of cancers. Nutrition Journal, 15(1), 99.

Antoine, J. M. (2010). Probiotics: Beneficial factors of the defence system. Proceedings of the Nutrition Society, 69(3), 429-433.

Arora, S., Jood, S., \& Khetarpaul, N. (2010). Effect of germination and probiotic fermentation on nutrient composition of barley based food mixtures. Food Chemistry, 119(2), 779-784

Arora, S., Jood, S., Khetarpaul, N., \& Goyal, R. (2009). Effect of germination and fermentation on ph, titratable acidity and chemical composition of pearl millet based food blends. Acta Alimentaria, 38(1), 107-115.

Arroyo-López, F., Querol, A., Bautista-Gallego, J., \& Garrido-Fernández, A. (2008). Role of yeasts in table olive production. International Journal of Food Microbiology, 128(2), 189-196.

Blandino, A., Al-Aseeri, M., Pandiella, S., Cantero, D., \& Webb, C. (2003). Cerealbased fermented foods and beverages. Food Research International, 36(6), 527-543.

Bonatsou, S., Benítez, A., Rodríguez-Gómez, F., Panagou, E. Z., \& ArroyoLópez, F. N. (2015). Selection of yeasts with multifunctional features for application as starters in natural black table olive processing. Food Microbiology, 46, 66-73.

Boudjou, S., Zaidi, F., Hosseinian, F., \& Oomah, B. D. (2014). Effects of faba bean (Vicia faba L.) flour on viability of probiotic bacteria during kefir storage. Journal of Food Research, 3(6), 13-13.
Brglez Mojzer, E., Knez Hrnčič, M., Škerget, M., Knez, Ž., \& Bren, U. (2016). Polyphenols: Extraction methods, antioxidative action, bioavailability and anticarcinogenic effects. Molecules, 21(7), 901.

Buri, R. C., von Reding, W., \& Gavin, M. H. (2004). Description and characterization of wheat aleurone. Cereal Foods World, 49(5), 274.

Calderon-Montano, M., Burgos-Morón, J. E., Pérez-Guerrero, C., \& López-Lázaro, M. (2011). A review on the dietary flavonoid kaempferol. Mini Reviews in Medicinal Chemistry, 11(4), 298-344.

Călinoiu, L. F., \& Vodnar, D. C. (2018). Whole grains and phenolic acids: A review on bioactivity, functionality, health benefits and bioavailability. Nutrients, 10(11), 1615.

Calixto-Campos, C. s., Carvalho, T. T., Hohmann, M. S., Pinho-Ribeiro, F. A., Fattori, V., Manchope, M. F., Zarpelon, A. C., Baracat, M. M., Georgetti, S. R., \& Casagrande, R. (2015). Vanillic acid inhibits inflammatory pain by inhibiting neutrophil recruitment, oxidative stress, cytokine production, and NFkB activation in mice. Journal of Natural Products, 78(8), 1799-1808.

Chandrasekara, A., \& Shahidi, F. (2011). Determination of antioxidant activity in free and hydrolyzed fractions of millet grains and characterization of their phenolic profiles by HPLC-DAD-ESI-MSn. Journal of Functional Foods, 3(3), 144-158.

Chao, C. y., Mong, M. C., Chan, K. C., \& Yin, M. C. (2010). Anti-glycative and antiinflammatory effects of caffeic acid and ellagic acid in kidney of diabetic mice. Molecular Nutrition \& Food Research, 54(3), 388-395.

Charalampopoulos, D., Wang, R., Pandiella, S., \& Webb, C. (2002). Application of cereals and cereal components in functional foods: A review. International Journal of Food Microbiology, 79(1-2), 131-141.

Chibuike Ogodo, A., Agwaranze, D. I., Aliba, N. V., Chukwuma Kalu, A., Blessing Nwaneri, C. Gwirtz, J., Garcia-Casal, M., Ranum, P., Pena-Rosas, J. \& GarciaCasal, M. (2014). Effect of traditional processing on phosphorus content and some anti nutritional factors of pearl millet (Pennisetum glaucum L.). Journal of Biological Sciences, 19(1), 66-75.

Choi, J.-G., Kang, O.-H., Lee, Y.-S., Oh, Y.-C., Chae, H.-S., Jang, H.-J., Kim, J.-H., Sohn, D.-H., Shin, D.-W., \& Park, H. (2008). In vitro activity of methyl gallate isolated from galla rhois alone and in combination with ciprofloxacin against clinical isolates of salmonella. Journal of Microbiology and Biotechnology, 18(11), 1848-1852.

Coda, R., Rizzello, C. G., \& Gobbetti, M. (2010). Use of sourdough fermentation and pseudo-cereals and leguminous flours for the making of a functional bread enriched of $\gamma$-aminobutyric acid (GABA). International Journal of Food Microbiology, 137(2-3), 236-245.

Coulibaly, A., Kouakou, B., \& Chen, J. (2011). Phytic acid in cereal grains: Structure, healthy or harmful ways to reduce phytic acid in cereal grains and their effects on nutritional quality. American Journal of Plant Nutrition and fertilization technology, 1(1), 1-22.

Dai, Q., Borenstein, A. R., Wu, Y., Jackson, J. C., \& Larson, E. B. (2006). Fruit and vegetable juices and Alzheimer's disease: The kame project. The American Journal of Medicine, 119(9), 751-759.

Dar, A., Singh, S., Palod, J., Al Ain, K., Kumar, N., Khadda, B., \& Farooq, F. (2017). Effect of probiotic, prebiotic and Synbiotic on hematological parameters of crossbred calves. International Journal of Livestock Research, 7(4), 127-136.

Das, A., Raychaudhuri, U., \& Chakraborty, R. (2012). Cereal based functional food of Indian subcontinent: A review. Journal of Food Science and Technology, 49(6), 665-672.

Devi, K. P., Malar, D. S., Nabavi, S. F., Sureda, A., Xiao, J., Nabavi, S. M., \& Daglia, M. (2015). Kaempferol and inflammation: From chemistry to medicine. Pharmacological Research, 99, 1-10.

Di Stefano, E., White, J., Seney, S., Hekmat, S., McDowell, T., Sumarah, M., \& Reid, G. (2017). A novel millet-based probiotic fermented food for the developing world. Nutrients, 9(5), 529

Dicko, M. H., Hilhorst, R., \& Traore, A. S. (2005). Indigenous west African plants as novel sources of polysaccharide degrading enzymes: Application in the reduction of the viscosity of cereal porridges. African Journal of Biotechnology, 4(10), 1095-1104.

Duodu, K. G., \& Awika, J. M. (2019). Phytochemical-related health-promoting attributes of sorghum and millets (pp. 225-258). Sorghum and Millets: Elsevier

Dykes, L., \& Rooney, L. (2007). Phenolic compounds in cereal grains and their health benefits. Cereal Foods World, 52(3), 105-111.

Dykes, L., \& Rooney, L. W. (2006). Sorghum and millet phenols and antioxidants. Journal of Cereal Science, 44(3), 236-251.

Eitsuka, T., Tatewaki, N., Nishida, H., Kurata, T., Nakagawa, K., \& Miyazawa, T. (2014). Synergistic inhibition of cancer cell proliferation with a combination of $\delta$ - 
tocotrienol and ferulic acid. Biochemical and Biophysical Research Communications, 453(3), 606-611.

Elkhalifa, A. E. O., Ahmed, S. A. A., \& Adam, S. (2007). Nutritional evaluation of Moringa Oleifera leaves and extract. Ahfad Journal, 24(2), 113.

Elkhalifa, A. E. O., \& Bernhardt, R. (2010). Influence of grain germination on functional properties of sorghum flour. Food Chemistry, 121(2), 387-392.

ElMaki, H. B., AbdelRahaman, S. M., Idris, W. H., Hassan, A. B., Babiker, E. E., \& El Tinay, A. H. (2007). Content of antinutritional factors and $\mathrm{HCl}$-extractability of minerals from white bean (Phaseolus vulgaris) cultivars: Influence of soaking and/or cooking. Food Chemistry, 100(1), 362-368.

Fahrioğlu, U., Dodurga, Y., Elmas, L., \& Seçme, M. (2016). Ferulic acid decreases cell viability and colony formation while inhibiting migration of MIA PaCa-2 human pancreatic cancer cells in vitro. Gene, 576(1), 476-482.

Foster-Powell, K., Holt, S. H., \& Brand-Miller, J. C. (2002). International table of glycemic index and glycemic load values: 20021'2. The American Journal of Clinical Nutrition, 76, 5-56.

Fuller, R. (1992). History and development of probiotics. In Probiotics (pp. 1-8). Dordrecht: Springer.

Gani, A., Wani, S., Masoodi, F., \& Hameed, G. (2012). Whole-grain cereal bioactive compounds and their health benefits: A review. Journal of Food Processing \& Technology, 3(3), 146-156.

Gliwa, J., Gunenc, A., Ames, N., Willmore, W. G., \& Hosseinian, F. S. (2011). Antioxidant activity of alkylresorcinols from rye bran and their protective effects on cell viability of PC-12 AC cells. Journal of Agricultural and Food Chemistry, 59(21), 11473-11482.

Grases, F., Prieto, R. M., \& Costa-Bauza, A. (2017). Dietary phytate and interactions with mineral nutrients. In Clinical aspects of natural and added phosphorus in foods (pp. 175-183). New York: Springer.

Gunenc, A., Yeung, M. H., Lavergne, C., Bertinato, J., \& Hosseinian, F. (2017). Enhancements of antioxidant activity and mineral solubility of germinated wrinkled lentils during fermentation in kefir. Journal of Functional Foods, 32, 72-79.

Hämäläinen, M., Nieminen, R., Vuorela, P., Heinonen, M., \& Moilanen, E. (2007). Anti-inflammatory effects of flavonoids: Genistein, kaempferol, quercetin, and daidzein inhibit STAT-1 and NF-KB activations, whereas flavone, isorhamnetin, naringenin, and pelargonidin inhibit only NF-KB activation along with their inhibitory effect on iNOS expression and NO production in activated macrophages. In Mediators of inflammation 2007.

Han, X., Shen, T., \& Lou, H. (2007). Dietary polyphenols and their biological significance. International Journal of Molecular Sciences, 8(9), 950-988.

Hassan, A. B., Ahmed, I. A. M., Osman, N. M., Eltayeb, M. M., Osman, G. A., \& Babiker, E. E. (2006). Effect of processing treatments followed by fermentation on protein content and digestibility of pearl millet (Pennisetum typhoideum) cultivars. Pakistan Journal of Nutrition, 5(1), 86-89.

Hegde, P. S., Anitha, B., \& Chandra, T. (2005). In vivo effect of whole grain flour of finger millet (Eleusine coracana) and kodo millet (Paspalum scrobiculatum) on rat dermal wound healing. Indian Journal of Experimental Biology, 43(3), 254-258.

Hejazi, S. N., Orsat, V., Azadi, B., \& Kubow, S. (2016). Improvement of the in vitro protein digestibility of amaranth grain through optimization of the malting process. Journal of Cereal Science, 68, 59-65.

Holzapfel, W. (2002). Appropriate starter culture technologies for small-scale fermentation in developing countries. International Journal of Food Microbiology, 75(3), 197-212.

Hooda, S., \& Jood, S. (2003). Effect of soaking and germination on nutrient and antinutrient contents of fenugreek (Trigonella foenum graecum L.). Journal of Food Biochemistry, 27(2), 165-176.

Hou, Y. Z., Zhao, G. R., Yang, J., Yuan, Y. J., Zhu, G. G., \& Hiltunen, R. (2004). Protective effect of Ligusticum chuanxiong and Angelica sinensis on endothelial cell damage induced by hydrogen peroxide. Life Sciences, 75(14), 1775-1786

Janicke, B., Hegardt, C., Krogh, M., Önning, G., Åkesson, B., Cirenajwis, H. M., \& Oredsson, S. M. (2011). The antiproliferative effect of dietary fiber phenolic compounds ferulic acid and p-coumaric acid on the cell cycle of Caco-2 cells. Nutrition and Cancer, 63(4), 611-622.

Jenner, A. M., Rafter, J., \& Halliwell, B. (2005). Human fecal water content of phenolics: The extent of colonic exposure to aromatic compounds. Free Radical Biology and Medicine, 38(6), 763-772.

Joye, I. (2019). Protein digestibility of cereal products. Foods, 8(6), 199

Ju, S. M., Kang, J. G., Bae, J. S., Pae, H. O., Lyu, Y. S., \& Jeon, B. H. (2015). The flavonoid apigenin ameliorates cisplatin-induced nephrotoxicity through reduction of p53 activation and promotion of PI3K Akt pathway in human renal proximal tubular epithelial cells. In Evidence-based complementary and alternative medicine 2015

Kamatham, S., Kumar, N., \& Gudipalli, P. (2015). Isolation and characterization of gallic acid and methyl gallate from the seed coats of Givotia rottleriformis Griff. And their anti-proliferative effect on human epidermoid carcinoma A431 cells. Toxicology Reports, 2, 520-529.

Kang, M.-S., Oh, J.-S., Kang, I.-C., Hong, S.-J., \& Choi, C.-H. (2008). Inhibitory effect of methyl gallate and gallic acid on oral bacteria. The Journal of Microbiology, 46(6), 744-750

Kaur, K. D., Jha, A., Sabikhi, L., \& Singh, A. (2014). Significance of coarse cereals in health and nutrition: A review. Journal of Food Science and Technology, 51(8), 1429-1441.

Kies, A. K., De Jonge, L. H., Kemme, P. A., \& Jongbloed, A. W. (2006). Interaction between protein, phytate, and microbial phytase. In vitro studies. Journal of Agricultural and Food Chemistry, 54(5), 1753-1758.

Kumar, B. V., Vijayendra, S. V. N., \& Reddy, O. V. S. (2015). Trends in dairy and nondairy probiotic products-a review. Journal of Food Science and Technology, 52(10), 6112-6124.

Kumari, D., Chandrasekara, A., \& Shahidi, F. (2019). Bioaccessibility and antioxidant activities of finger millet food phenolics. Journal of Food Bioactives, 6, 100109.

Lamsal, B., \& Faubion, J. (2009). The beneficial use of cereal and cereal components in probiotic foods. Food Reviews International, 25(2), 103-114.

Lee, D., \& Imm, J. Y. (2017). AMP kinase activation and inhibition of nuclear factor-kappa B (NF-kB) translocation contribute to the anti-inflammatory effect of tricin. Journal of Food Biochemistry, 41(2), e12293.

Lee, D., \& Imm, J.-Y. (2018). Antiobesity effect of tricin, a methylated cereal flavone, in high-fat-diet-induced obese mice. Journal of Agricultural and Food Chemistry, 66(38), 9989-9994.

Leroy, F., \& De Vuyst, L. (2004). Lactic acid bacteria as functional starter cultures for the food fermentation industry. Trends in Food Science \& Technology, 15(2), 67-78.

Liu, R. H. (2013). Dietary bioactive compounds and their health implications. Journal of Food Science, 78(s1), A18-A25.

Liukkonen, K.-H., Katina, K., Wilhelmsson, A., Myllymaki, O., Lampi, A.-M., Kariluoto, S., Piironen, V., Heinonen, S.-M., Nurmi, T., \& Adlercreutz, H. (2003). Processinduced changes on bioactive compounds in whole grain rye. Proceedings of the Nutrition Society, 62(1), 117-122.

Mbithi-Mwikya, S., Van Camp, J., Yiru, Y., \& Huyghebaert, A. (2000). Nutrient and antinutrient changes in finger millet (Eleusine coracan) during sprouting. LWT- Food Science and Technology, 33(1), 9-14.

McDonough, C., Awika, J., Turner, N., Xu, L., \& Rooney, L. (2004). The potential for use of antioxidants from sorghum bran in foods as countermeasures against radiation damage in space AACC Annual Meeting Abstracts.

Mennen, L. I., Walker, R., Bennetau-Pelissero, C., \& Scalbert, A. (2005). Risks and safety of polyphenol consumption. The American Journal of Clinical Nutrition, 81(1), 3265-329S.

Mohapatra, D., Patel, A. S., Kar, A., Deshpande, S. S., \& Tripathi, M. K. (2019). Effect of different processing conditions on proximate composition, anti-oxidants, anti-nutrients and amino acid profile of grain sorghum. Food Chemistry, 271, 129-135.

Naczk, M., \& Shahidi, F. (2004). Extraction and analysis of phenolics in food. Journal of Chromatography A, 1054(1-2), 95-111.

Narasimhan, A., Chinnaiyan, M., \& Karundevi, B. (2015). Ferulic acid regulates hepatic GLUT2 gene expression in high fat and fructose-induced type-2 diabetic adult male rat. European Journal of Pharmacology, 761, 391-397.

Narukawa, T., Hioki, A., \& Chiba, K. (2012). Speciation and monitoring test for inorganic arsenic in white rice flour. Journal of Agricultural and Food Chemistry, 60(4), 1122-1127.

Nassar, A. G., Mubarak, A. E., \& El-Beltagy, A. E. (2008). Nutritional potential and functional properties of Tempe produced from mixture of different legumes. 1: Chemical composition and nitrogenous constituent. International Journal of Food Science \& Technology, 43(10), 1754-1758.

Nirmala, P., \& Ramanathan, M. (2011). Effect of myricetin on 1, 2 dimethylhydrazine induced rat colon carcinogenesis. Journal of Experimental Therapeutics \& Oncology, 9(2), 101-108.

Nkhata, S. G., Ayua, E., Kamau, E. H., \& Shingiro, J. B. (2018). Fermentation and germination improve nutritional value of cereals and legumes through activation of endogenous enzymes. Food Science \& Nutrition, 6(8), 2446-2458.

Nyanzi, R., \& Jooste, P. (2012). Cereal-based functional foods, probiotics. In E. Rigobelo (Ed.), ISBN: 978-953-51-0776-7 InTech. https://doi.org/10.5772/50120. 
Oghbaei, M., \& Prakash, J. (2016). Effect of primary processing of cereals and legumes on its nutritional quality: A comprehensive review. Cogent Food \& Agriculture, 2(1), 1136015.

Ogunremi, O. R., Agrawal, R., \& Sanni, A. I. (2015). Development of cereal-based functional food using cereal-mix substrate fermented with probiotic strainPichia kudriavzevii OG 32. Food Science \& Nutrition, 3(6), 486-494.

Ostlund Jr., R. E. (2002). Phytosterols in human nutrition. Annual Review of Nutrition, 22(1), 533-549.

Pandey, K. R., Naik, S. R., \& Vakil, B. V. (2015). Probiotics, prebiotics and synbiotics-a review. Journal of Food Science and Technology, 52(12), 7577-7587.

Peyer, L. C., Zannini, E., \& Arendt, E. K. (2016). Lactic acid bacteria as sensory biomodulators for fermented cereal-based beverages. Trends in Food Science \& Technology, 54, 17-25

Piironen, V., Toivo, J., \& Lampi, A.-M. (2002). New data for cholesterol contents in meat, fish, milk, eggs and their products consumed in Finland. Journal of Food Composition and Analysis, 15(6), 705-713.

Pradeep, P., \& Sreerama, Y. N. (2018). Phenolic antioxidants of foxtail and little millet cultivars and their inhibitory effects on a-amylase and a-glucosidase activities. Food Chemistry, 247, 46-55.

Pragasam, S. J., Venkatesan, V., \& Rasool, M. (2013). Immunomodulatory and antiinflammatory effect of p-coumaric acid, a common dietary polyphenol on experimental inflammation in rats. Inflammation, 36(1), 169-176.

Prior, R. L., Wu, X., \& Schaich, K. (2005). Standardized methods for the determination of antioxidant capacity and phenolics in foods and dietary supplements. Journal of Agricultural and Food Chemistry, 53(10), 4290-4302.

Raes, K., Knockaert, D., Struijs, K., \& Van Camp, J. (2014). Role of processing on bioaccessibility of minerals: Influence of localization of minerals and antinutritional factors in the plant. Trends in Food Science \& Technology, 37(1), 32-41.

Salas, C. E., Dittz, D., \& Torres, M.-J. (2018). Plant proteolytic enzymes: Their role as natural pharmacophores. In Biotechnological applications of plant proteolytic enzymes (pp. 107-127). Cham: Springer.

Salmerón, I. (2017). Fermented cereal beverages: From probiotic, prebiotic and synbiotic towards nanoscience designed healthy drinks. Letters in Applied Microbiology, 65(2), 114-124.

Sawant, A. A., Thakor, N. J., Swami, S. B., Divate, A. D., \& Vidyapeet, B. S. (2012). Physical and sensory characteristics of ready-to-eat food prepared from finger millet based composite mixer by extrusion. Agricultural Engineering International: CIGR Journal, 15(1), 100-105.

Shahidi, F., \& Chandrasekara, A. (2013). Millet grain phenolics and their role in disease risk reduction and health promotion: A review. Journal of Functional Foods, 5(2), 570-581.

Shahidi, F., \& Peng, H. (2018). Bioaccessibility and bioavailability of phenolic compounds. Journal of Food Bioactives, 4, 11-68.

Shahidi, F., \& Yeo, J. (2018). Bioactivities of phenolics by focusing on suppression of chronic diseases: A review. International Journal of Molecular Sciences, 19(6), 1573.

Sindhu, S. C., \& Khetarpaul, N. (2001). Probiotic fermentation of indigenous food mixture: Effect on antinutrients and digestibility of starch and protein. Journal of Food Composition and Analysis, 14(6), 601-609.

Singh, A., Gupta, S., Kaur, R., \& Gupta, H. (2017). Process optimization for antinutrient minimization of millets. Asian Journal of Dairy and Food Research, 36(4), 322-326

Singh, A. k., Rehal, J., Kaur, A., \& Jyot, G. (2015). Enhancement of attributes of cereals by germination and fermentation: A review. Critical Reviews in Food Science and Nutrition, 55(11), 1575-1589.

Siwela, M., Taylor, J. R., de Milliano, W. A., \& Duodu, K. G. (2007). Occurrence and location of tannins in finger millet grain and antioxidant activity of different grain types. Cereal Chemistry, 84(2), 169-174.

Subba Rao, M., \& Muralikrishna, G. (2002). Evaluation of the antioxidant properties of free and bound phenolic acids from native and malted finger millet (Ragi, Eleusine coracana Indaf-15). Journal of Agricultural and Food Chemistry, 50(4), 889-892.

Taguri, T., Tanaka, T., \& Kouno, I. (2006). Antibacterial spectrum of plant polyphenols and extracts depending upon hydroxyphenyl structure. Biological and Pharmaceutical Bulletin, 29(11), 2226-2235.

Timotheo, C., \& Lauer, C. (2018). Toxicity of vegetable tannin extract from Acacia mearnsii in Saccharomyces cerevisiae. International journal of Environmental Science and Technology, 15(3), 659-664.

USDA. (2018). USDA national nutrient database for standard reference, release 27.
Verni, M., Rizzello, C. G., \& Coda, R. (2019). Fermentation biotechnology applied to cereal industry by-products: Nutritional and functional insights. Frontiers in Nutrition, 6, 42

Waniska, R. D. (2000). Structure, phenolic compounds, and antifungal proteins of sorghum caryopses. In Technical and institutional options for sorghum grain mold management: Proceedings of an international consultation. (pp. 18-19). Patancheru: ICRISAT.

Watanabe, N., Hirayama, R., \& Kubota, N. (2007). The chemopreventive flavonoid apigenin confers radiosensitizing effect in human tumor cells grown as monolayers and spheroids. Journal of Radiation Research, 48(1), 45-50.

Willett, W., Manson, J., \& Liu, S. (2002). Glycemic index, glycemic load, and risk of type 2 diabetes. The American Journal of Clinical Nutrition, 76(1), 274S-280S.

Yeh, R.-D., Chen, J.-C., Lai, T.-Y., Yang, J.-S., Yu, C.-S., Chiang, J.-H., Lu, C.-C., Yang, S.T., Yu, C.-C., \& Chang, S.-J. (2011). Gallic acid induces G0/G1 phase arrest and apoptosis in human leukemia HL-60 cells through inhibiting cyclin D and $\mathrm{E}_{\text {, }}$ and activating mitochondria-dependent pathway. Anticancer Research, 31(9), $2821-2832$.

\section{Publisher's Note}

Springer Nature remains neutral with regard to jurisdictional claims in published maps and institutional affiliations.

Ready to submit your research? Choose BMC and benefit from:

- fast, convenient online submission

- thorough peer review by experienced researchers in your field

- rapid publication on acceptance

- support for research data, including large and complex data types

- gold Open Access which fosters wider collaboration and increased citations

- maximum visibility for your research: over $100 \mathrm{M}$ website views per year

At $\mathrm{BMC}$, research is always in progress.

Learn more biomedcentral.com/submissions 